\title{
Multi-Satellite and Sensor Derived Trends and Variation of Snow Water Equivalent on the High-Latitudes of the Northern Hemisphere
}

\author{
Reginald R. Muskett \\ Geophysical Institute, University of Alaska Fairbanks, Fairbanks, USA \\ Email: rrmuskett@alaska.edu
}

Received September 3, 2011; revised November 2, 2011; accepted December 25, 2011

\begin{abstract}
Utilizing more than 30 years of satellite-microwave sensor derived snow water equivalent data on the high-latitudes of the northern hemisphere we investigate regional trends and variations relative to elevation. On the low-elevation tundra regions encircling the Arctic we find high statistically significant trends of snow water equivalent. Across the high Arctic Siberia and Far East Russia through North America and northern Greenland we find increasing trends of snow water equivalent with local region variations in strength. Yet across the high Arctic of western Russia through Norway we find decreasing trends of snow water equivalent of varying strength. Power density spectra identify significant power at quasi-biennial and associated lunar nodal cycles. These cycles of the upper atmosphere circulation, ENSO and ocean circulation perturbations from tides forms the causative linkage between increasing snow water equivalent on lowelevation tundra landscapes and decreasing coastal sea ice cover as part of the Arctic system energy and mass cycles.
\end{abstract}

Keywords: Arctic; Snow Water Equivalent; Multi-Satellite; Microwave; Trends and Variations

\section{Introduction}

The boreal winter snow cover and depth play many roles in the Earth's climate, energy and water cycles. These include albedo, insulation for permafrost and vegetation, ecosystems, and a source of water in spring to lakes, rivers, soil moisture and groundwater [1-5]. Snow water equivalent, i.e. the mass of snow is a critical parameter of the Earth $[6,7]$.

The Earth is currently experiencing the latest inter-glacial era of a long period of glaciations that stretch back to the late Tertiary [8]. To date our most robust global data records for snow water equivalent are derived by satellite-based microwave sensor systems and retrieval algorithms, which began in late 1978 and continue. Over this period much has been experimented and learned of the microwave characteristics of snow and sensed from an orbital perspective. In addition our abilities to engineer and maintain in precise orbits for artificial satellites has evolved into precise global measurement network systems, which includes the Global Positioning System (GPS).

In our study we investigate snow water equivalent, the water equivalent mass of snow on the northern high latitudes of the Arctic non-glaciated land regions. Our datasets for snow water equivalent derive from satellite microwave sensor systems and retrieval algorithms. These are the Scanning Multi-Channel Microwave Radiometer
(SMMR), the Special Sensor Microwave/Imager (SSM/I) and the Advanced Microwave Scanning Radiometer for the NASA Earth Observation System (AMSR-E).

To interrogate the datasets we employ mathematical techniques from Inverse Theory and time series analysis [9-12]. Our objective is to search the datasets for regional trends, variations and significance levels of snow water equivalent. This will serve as aid in assessments of changes in boreal snow water equivalent over the period of measurement from November 1978 through May 2010.

\section{Snow Water Equivalent Datasets}

We investigate snow water equivalent estimates derived from satellite based multichannel microwave sensor systems from late 1978 through mid-2010. The NASA Nimbus-7 SMMR operated from November 1978 through August 1987. The Defense Meteorological Satellite Program now operated by NOAA, F-08 through F-13 SSM/I sensors operated from September 1987 through May 2007. AMSR-E onboard NASA Aqua was operational from June 2002 to 4 October 2011.

The National Snow and Ice Data Center (NSIDC), as part of the NASA Distributed Active Archive Center System distribute the datasets in hierarchical data format and binary files. More background information on algorithms and measurement theory, processing, projection-grids, sa- 
tellites and sensors can be found at NSIDC (http://nsidc. org). Table 1 provides a brief summary of pertinent sensor specifications.

Satellite-based passive microwave sensors measure brightness temperature and emissivity of radiation [13-16]. The signal received at the satellite sensor originates from the surface with contributions from the snow pack and sub-snow pack interface. Microwave channels used are chosen for minimal atmosphere interference. Processing of the raw data takes into account antenna orientation, orbit (including solar and tide effects) and timing [17]. Algorithms developed during the SMMR and SSM/I eras were refined as better knowledge of physics regarding atmosphere, snow pack (density, grain size, depth hoar and moisture), terrain (complexity) and vegetation (canopy closure, internal scatters and littoral scatters) became known $[15,18,19]$. The AMSR-E snow water equivalent algorithm was initially based on work published in [14] and updated by work published in [20-22]. Subsequent improvements have been made to the SSM/I and AMSRE snow water equivalent algorithms [22-26]. Monthly composite climatology from the sensors is processed from daily passed-retrievals through averaging.

All three sensors are subject to uncertainties of the physical state of snow packs including depth hoar and metamorphism $[27,28]$. Under-estimations can occur on mountains of complex geometry, along marine-coastlines where signals from ocean bodies are partly convolved, and the beginning and ending of the snow season when snow depths are thin and moist [16]. Ocean masks are used to help mitigate strong contrasts of land-ocean brightness temperature and emissivity. Noise from transitory atmosphere conditions is removed using a five-day filtering for SSM/I retrievals for instance. Missing retrievals due to swath coverage gaps are interpolated from neighboring swaths. Adjustment for tall and dense vegetation uses vegetation indices derived during the sensor eras with most

Table 1. Summary of SMMR, SSM/I and AMSR-E sensors.

\begin{tabular}{|c|c|c|c|}
\hline Parameter & $\begin{array}{l}\text { SMMR } \\
\text { NIMBUS-7 }\end{array}$ & $\begin{array}{l}\text { SSM/I } \\
\text { DMSP-F08, } \\
\text { F10, F11, F13 }\end{array}$ & $\begin{array}{l}\text { AMSR-E } \\
\text { Aqua }\end{array}$ \\
\hline Period & $\begin{array}{l}\text { Nov. } 1978 \text { thru } \\
\text { Aug. } 1987 \\
\text { 48-Hour } \\
\text { Acquisitions }\end{array}$ & $\begin{array}{l}\text { Sept. } 1987 \\
\text { thru May } 07 \\
\text { 24-Hour } \\
\text { Acquisitions }\end{array}$ & $\begin{array}{l}\text { June } 2002 \\
\text { thru Sept. } 11 \\
\text { 24-Hour } \\
\text { Acquisitions }\end{array}$ \\
\hline Freq. (GHz) & $\begin{array}{l}6.6,10.7,18,21 \text {, } \\
\text { and } 37\end{array}$ & $\begin{array}{l}19.3,22.3 \\
36.5,85.5\end{array}$ & $\begin{array}{l}\text { 6.9, 10.7, 18.7, } \\
23.8,36.5,89.0\end{array}$ \\
\hline Polarization & $\begin{array}{l}\text { Vertical and } \\
\text { Horizontal }\end{array}$ & $\begin{array}{l}\text { Vertical } \\
\text { and Horizontal }\end{array}$ & $\begin{array}{l}\text { Vertical } \\
\text { and Horizontal }\end{array}$ \\
\hline IFOV (km) & $\begin{array}{l}55 \times 41(18 \mathrm{GHz}) \\
37 \times 28(37 \mathrm{GHz})\end{array}$ & $\begin{array}{l}37 \times 28(37 \mathrm{GHz}) \\
15 \times 13(85.5 \mathrm{GHz})\end{array}$ & $\begin{array}{l}74 \times 43(6.9 \mathrm{GHz}) \\
14 \times 8(36.5 \mathrm{GHz}) \\
6 \times 4(89.0 \mathrm{GHz})\end{array}$ \\
\hline
\end{tabular}

docs/daac/ae_swe_ease-grids.gd.html). Surface meteorolorecent ones from MODIS [18,29] (http://nsidc.org/data/ gical station data over the northern hemisphere were used in calibration and re-calibration of the algorithms [22]. Inter-comparison and validation campaigns on sites over the mid-to-high northern latitudes have been undertaken $[15,19,26,30]$.

\subsection{SMMR-SSM/I}

Snow water equivalent estimates in units of millimeters were derived using the horizontally polarized difference algorithm for the 19 and $37 \mathrm{GHz}$ channels from daily orbit swath acquisitions $[14,15,31]$. Nominal spatial resolution for SMMR is about 55 by $41 \mathrm{~km}(18 \mathrm{GHz})$ and 37 by $28 \mathrm{~km}(37 \mathrm{GHz})$. Nominal spatial resolution for SSM/I is about 37 by $28 \mathrm{~km}(37 \mathrm{GHz})$ and 15 by $13 \mathrm{~km}(85.5$ $\mathrm{GHz}$ ). SMMR operated in and orbit that allowed for global coverage within 48-hours (every-other day acquisition). SSM/I operates in a faster orbit to allow global same-day day-nighttime acquisitions. Figure 1 shows an example of SSM/I ascending mode brightness temperatures (Kelvin) $19 \mathrm{GHz}$ (A) and $37 \mathrm{GHz}$ (B) during 10 March 2006.

\subsection{AMSR-E}

Based on SMMR-SSM/I algorithms the AMSR-E estimates snow water equivalent in units of millimeters using the horizontally polarized difference algorithm for the 7, 37 and $89 \mathrm{GHz}$ channels [21,22,32,33]. Nominal spatial resolution varies from about 6 by $4 \mathrm{~km}$ in the 89 $\mathrm{GHz}$ channel up to 74 by $43 \mathrm{~km}$ in the $7 \mathrm{GHz}$ channel. Global coverage from NASA-Aqua (EOS-PM) allows for same-day daytime and nighttime acquisitions.

\subsection{Grid}

The processed data were gridded in the equal-area scalable Earth (EASE) projection system at 25-km grid intervals [31,33]. For our purposes we project the data into the World Geodetic System (WGS) with WGS-84 ellipsoid and Earth Geopotential Model 1996, consistent with the International Terrestrial Reference Frame 2005 epoch [34-36]. For co-location with the Digital Elevation Model data we employ bi-linear least squares interpolation to a $5 \mathrm{~km}$ grid. We employ a planetocentric graticule with positive East, $0^{\circ}$ to $360^{\circ}$ longitudes. This removes the E$\mathrm{W}\left( \pm 180^{\circ}\right)$ ambiguity.

\subsection{Digital Elevation Model Data}

Our source for land elevation data is the ESA funded Altimetry Corrected Elevation version 2 Digital Elevation Model (DEM) [37]. This model is derived from the Shuttle Radar Topography Mission DEM (finished) and ESA multi-mission satellite radar altimetry (ESA ERS-1\&2 

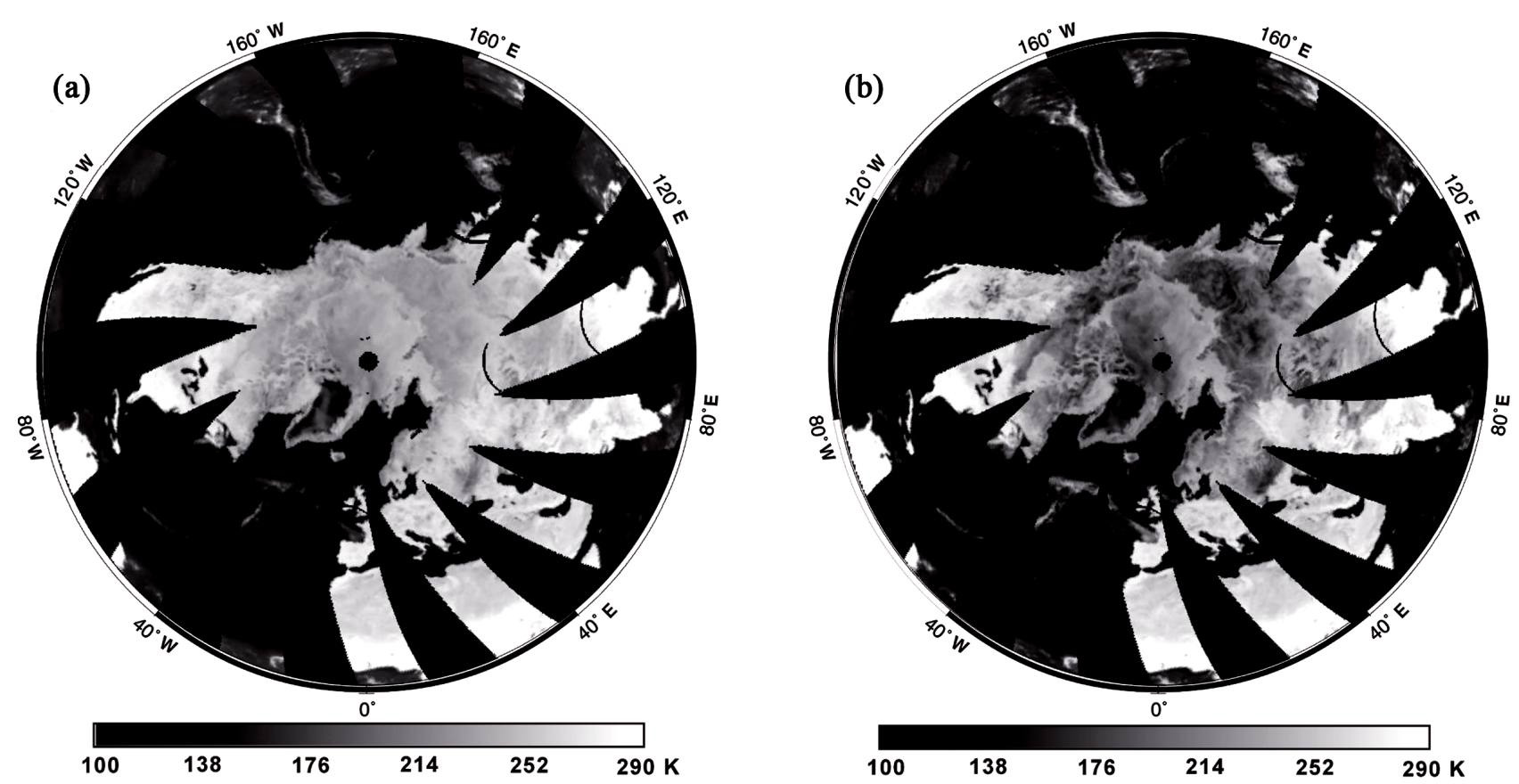

Figure 1. SSM/I 19 GHz (a) and 37 GHz (b) brightness temperature (Kelvin) measured on 10 March 2006 (ascending mode) used in the algorithm for snow water equivalent retrieval.

and Envisat) [38]. We use the 15-degree tiles, 3-arc second posting, reference in the EGM96 WGS84 system, consistent with the International Terrestrial Reference Frame 2005. For co-location matching with the snow water equivalent data we employ bi-linear least squares interpolation (up-sampling) to a $5 \mathrm{~km}$ grid.

\section{Methodology}

Our methodology utilizes mathematical techniques from Inverse Theory through the investigation of time series [9-12]. These we employ to derive least squares trends, analysis of variations, significance levels and error.

It has long been known that topography plays important physical roles in influencing the magnitude of precipitation, i.e. the orographic lift by terrain elevation. It has also long been known that our satellite microwave sensors perform with less accuracy on regions of complex terrain due to slope-aspect and the limitations from the instantaneous field of view of the sensors.

For these reasons we apply position co-location of the snow water equivalent data with the DEM. Since our datasets are processed to have matching earth-centered grids sorting and identifying same-location elevation with snow water equivalent can be done efficiently with Linux/UNIX tools and shell scripting for batch processing. Figure 2 shows the DEM (A) and an example of snow water equivalent with same grid and geolocations over the Arctic. The snow water equivalent data are for 3 March 2006.

With co-located elevation-snow water equivalent we then extract the data filling the region beginning at $65^{\circ} \mathrm{N}$ latitude. From these we derive the $65^{\circ} \mathrm{N}$ region monthly means, standard deviations and standard errors. At this point we then derive calibration factors of the regionalized monthly time series SMMR, SSM/I and AMSR-E snow water equivalents using least squares techniques to mitigate bias offsets of the data groups. We then apply the calibration factors back to the $65^{\circ} \mathrm{N}$ datasets using seasonal sinusoids to proportion the calibrations by month.

Having mitigated bias offsets of the data groups we now have a calibrated and consistent dataset covering the non-glaciated land region from $65^{\circ} \mathrm{N}$ and higher. To investigate the regional trends and variations we develop extraction regions of interest. Figure 2(c) shows our extraction region on the Arctic and the underlying DEM with elevations in the range from 0 to $100 \mathrm{~m}$. These cover the Arctic Coastal Plain of Alaska and the lower Lena watershed for instance. Figure 2(d) gives an example of the calibrated and co-located snow water equivalent data in the elevation range from 0 to $100 \mathrm{~m}$, 3 March 2006. From these we derive the mean, standard deviation and standard error of snow water equivalent and then derive the least squares trends, p-values and significance levels. Figure 3 shows the regionalized mean snow water equivalent time series in the elevation range from 0 to $100 \mathrm{~m}$, non-calibrated (a) and calibrated (b). In Figure 3(a) we denote the satellite-era sensors by color: Red diamonds denote SMMR, Blue squares denote SMM/I and Green triangles denote AMSR-E. The very obvious bias offsets of all three are evident. This we can understand is mostly a function of averaging: mostly temporal averaging from the differing orbits from SMMR to SSM/I and spatial 

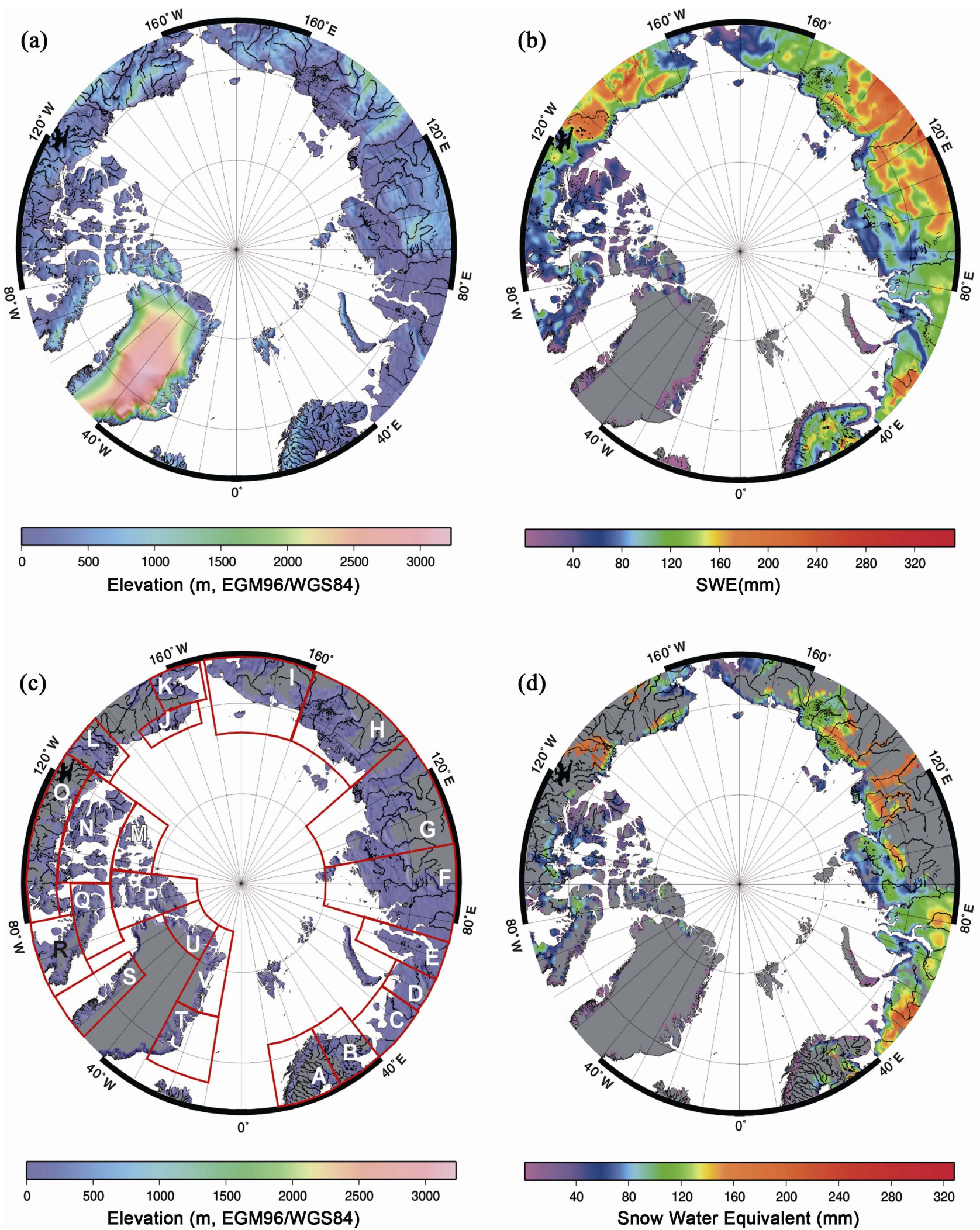

Figure 2. $65^{\circ} \mathrm{N}$ region of interest for snow water equivalent (SWE) investigation. (a) ESA funded Altimetry Corrected Elevation Digital Elevation Model version 2; (b) SSM/I snow water equivalent on 3 March 2006; (c) Elevations in the range of 0 to $100 \mathrm{~m}$ and sub-regions referenced in Table 2 and Figure 6; (d) Elevation co-located SWE on 3 March 2006. Grey color corresponds to no data. 


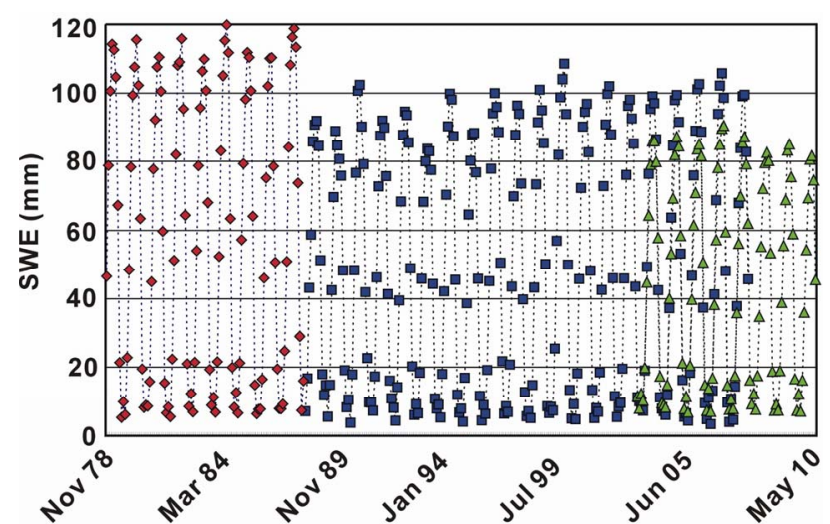

(a)

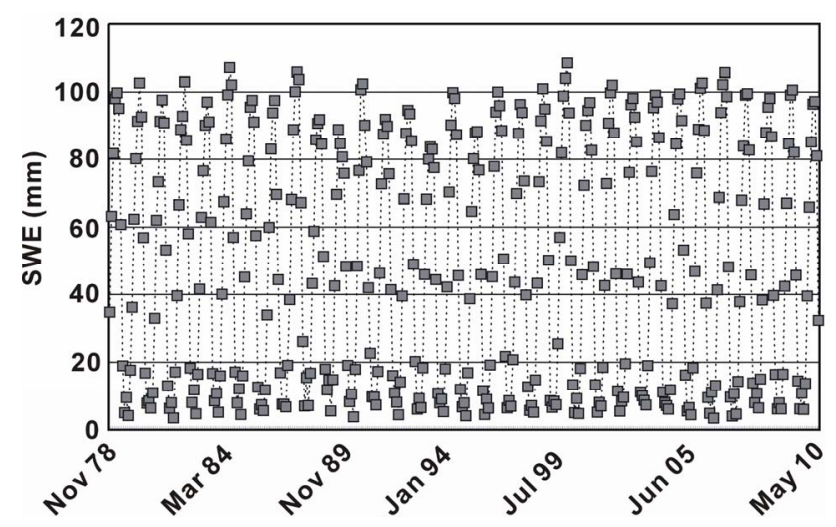

(b)

Figure 3. Regionalized $65^{\circ} \mathrm{N}$ mean snow water equivalent time series. (a) Satellite era sensors color-coded: Red-SSMR, Blue-SSM/I and Green-AMSR-E; (b) Calibrated regionalized mean snow water equivalent time series.

averaging from SS/I through AMSR-E given the different instantaneous fields of view of the sensors.

\section{Results and Discussion}

Figure 4 shows the $65^{\circ} \mathrm{N}$ regionalized mean snow water equivalent monthly time series and trend. The least squares trend indicates snow water equivalent is increasing by $0.20 \pm 0.07 \mathrm{~mm} / \mathrm{yr}$ with a p-value of $1.72 \mathrm{E}-09$ (100\% significance level) from November 1978 through May 2010.

Physics controlling snow cover and snow water equivalent, i.e. precipitation and processes of climate are nonstationary $[39,40]$. A factor in nonstationarity is telecomnection processes at the global scale such as the El Niño/Southern Oscillation (ENSO) [41,42].

In Figure 4 we highlight two ENSO events. Winter 1993 experienced a strong La Niña (cool ENSO phase) shown by the blue circle, and winter 1998 experienced a strong El Niño (warm ENSO phase) shown by the red circle. Our calibrated time series captures this physical teleconnection of equatorial ocean surface temperature and extratropical precipitation in the northern high latitudes.

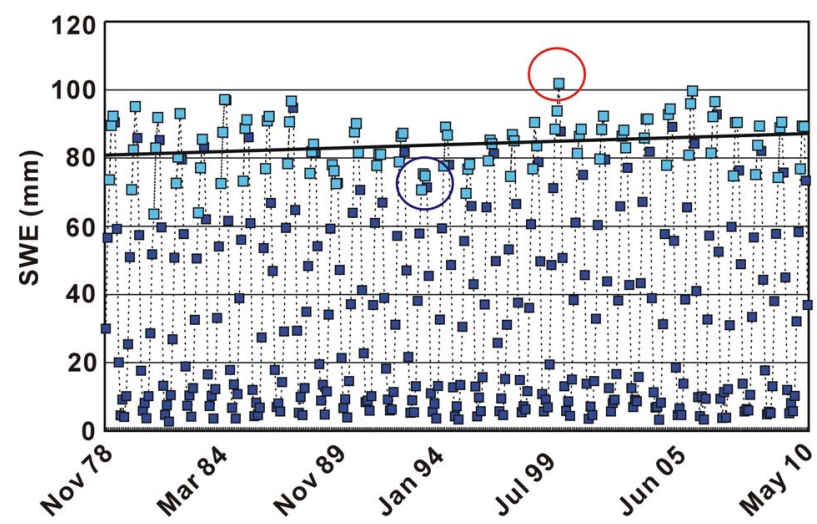

Figure 4. Calibrated regionalized $65^{\circ} \mathrm{N}$ mean snow water equivalent time series. Light-blue squares denote JanuaryFebruary-March months used for least squared derived trend (Black-line). Blue-circle identifies strong La Niña cold-phase ENSO during winter 1993 and red-circle identifies strong El Niño warm-phase ENSO during winter 1998.

Winter northern hemisphere atmosphere circulation and variability can be described as the coupled Arctic and North Atlantic Oscillation [43]. Together with the Pacific North America Oscillation these circulation and energy patterns control the advection of energy and mass and linked surface processes that influence precipitation, storminess and surface temperature on decadal, interannual, seasonal, monthly and less timescales [44]. The quasi-biennial persistence of the patterns stems from coupling of tropical and extratropical sea surface temperatures and external forcing from in particular Eurasian snow cover [45].

Figures 5(a) and (b) show the discrete power density spectra of the detrended monthly series, and Figures 5(c) and (d) show the discrete power density spectra of the variance of detrended monthly series. Figures 5(a) and (c) use 256 samples from the series beginning and Figures 5(b) and (d) use 256 samples from the series ending. We use these overlapping short sample lengths to satisfy the $2^{\mathrm{N}}$ criterion of the Discrete Fast Fourier algorithm and to avoid zero padding and windowing that will reduce power and pose convolution of window artifacts. The red continuous lines are significance levels, 95\% lower and 99\% upper based on a reference red-noise chi-squared distribution using deviations and variances from the monthly series. Figures 5(a) and (b) show significant power at the frequencies corresponding to the 12-month, 6-month, 4-month, 3-month and quasi-2-month cycles. At low frequencies significant power is at 1.2 and 10.75-year cycles in Figure 5(a) and at 2-, 10.75-, and 21.5-year cycles in Figure 5(b). The power density spectra of the variance series show significant low frequency power at 19.85-year cycles in Figures 5(c) and (d). The 19.85year cycle is a likely alias of the 18.61-year lunar nodal cycle $[46,47]$. 

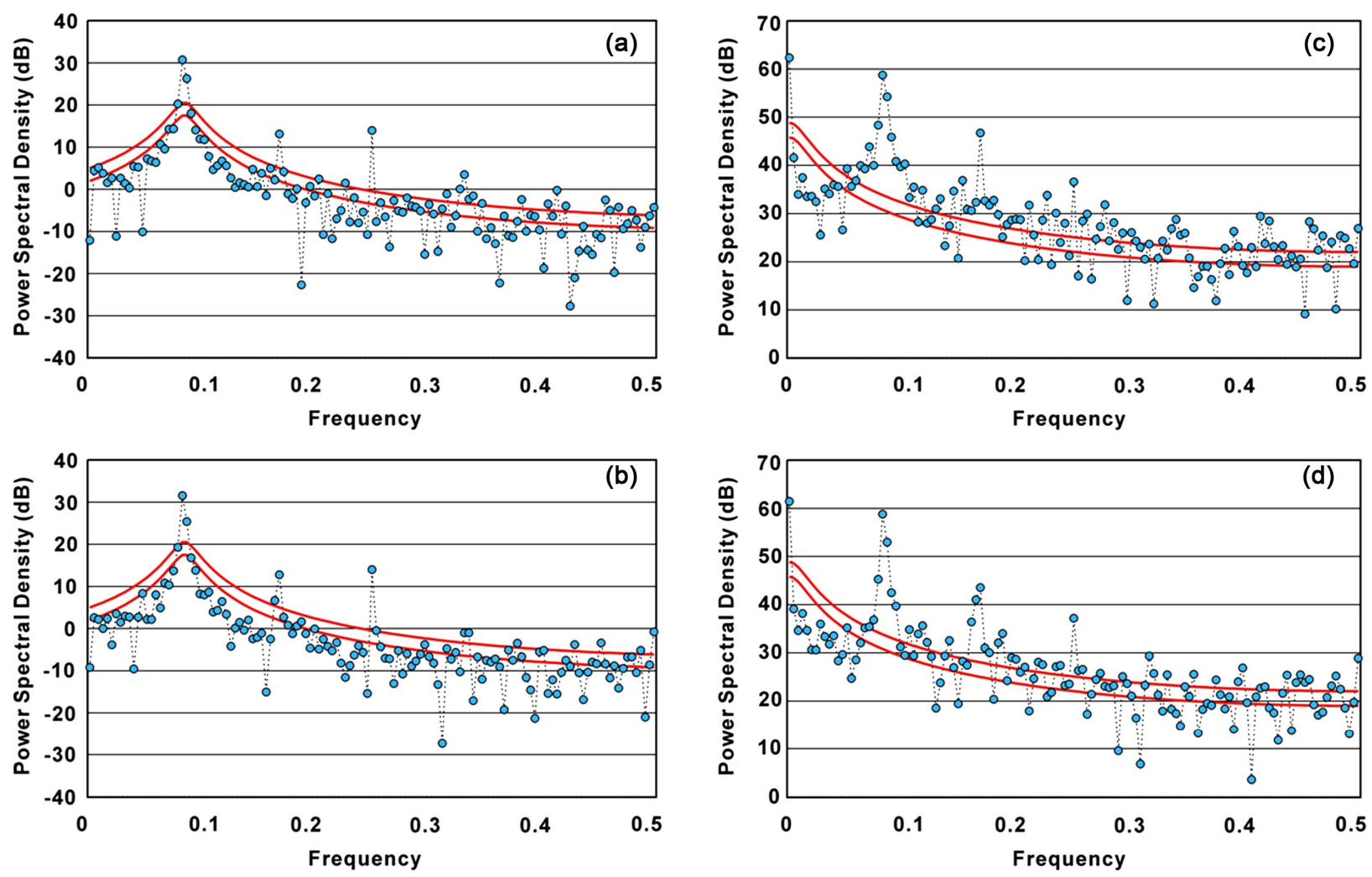

Figure 5. Power density spectra (dB) of the calibrated regionalized $65^{\circ} \mathrm{N}$ mean snow water equivalent and variance time series. (a-b) Power density spectra of 256 samples from series beginning, (a) and series ending, (b) are shown with reference red-noise spectra at $95 \%$ significance (lower red line) and $99 \%$ significance (upper red line). (c) and (d) Power density spectra of 256 samples from the variance series beginning, (c) and variance series ending, (d) are show with reference red-noise spectra at $95 \%$ significance (lower red line) and $99 \%$ significance (upper red line).

Figure 6 shows 22 sub-region regionalized mean snow water equivalent monthly time series and trends (Table 2) on the northern hemisphere distributed clock-wise from $10^{\circ} \mathrm{E}$ through $10^{\circ} \mathrm{W}$ (Figure 2(c)). The time series vertical axis is the same for all the plots. Northwest Europe and Russia (Figure 6 and Table 2 A through E) have decreasing trends of snow water equivalent. Northern Siberia, Far East Russia and North America and Greenland (Figure 6 and Table $2 \mathrm{~F}$ through V) all show increasing trends. All have very low P-Values indicating high significance over the period of measurement.

Figure 6(J), the Arctic Coastal Plain of Alaska shows mean snow water equivalent values during winter 1989 were exceptionally large. Precipitation records for 1989 at Barrow, Alaska corroborate this result [48].

The mean snow water equivalent varies over all the regions. Interestingly the largest magnitudes of regional mean snow water equivalent occur across northern Siberia. Contrasting to this the smallest magnitudes of regional mean snow water equivalent occur across eastern North America and Greenland.

Our regionalized trends show statistically significant increasing snow water equivalent on low-elevation tundra landscapes from northern Eurasia through North Ame- rica and Greenland. On low-elevation tundra landscapes from northern Norway through northwest Russia there are statistically significant decreasing snow water equivalent. These indicate a likely influence from the Atlantic inflow and perturbation by the North Atlantic Oscillation on the regional snow water equivalent trends [46].

Our analysis of the power density spectra has identified significant power at quasi-biennial and associated lunar nodal cycles. The quasi-biennial (upper atmosphere circulation and ENSO) and lunar nodal cycles (ocean circulation perturbations from tides) forms the causative linkage between increasing snow water equivalent on lowelevation tundra landscapes and decreasing coastal sea ice cover as a subsystem of the Arctic system energy and mass cycles.

\section{Conclusions}

We investigate the more than 30-year record of multi-satellite and multi-microwave sensors derived snow water equivalent on the high-latitudes of the northern hemisphere land regions. We accomplish this through application of Inverse Theory. This includes least squares calibration of the sensor snow water equivalent retrievals. We 

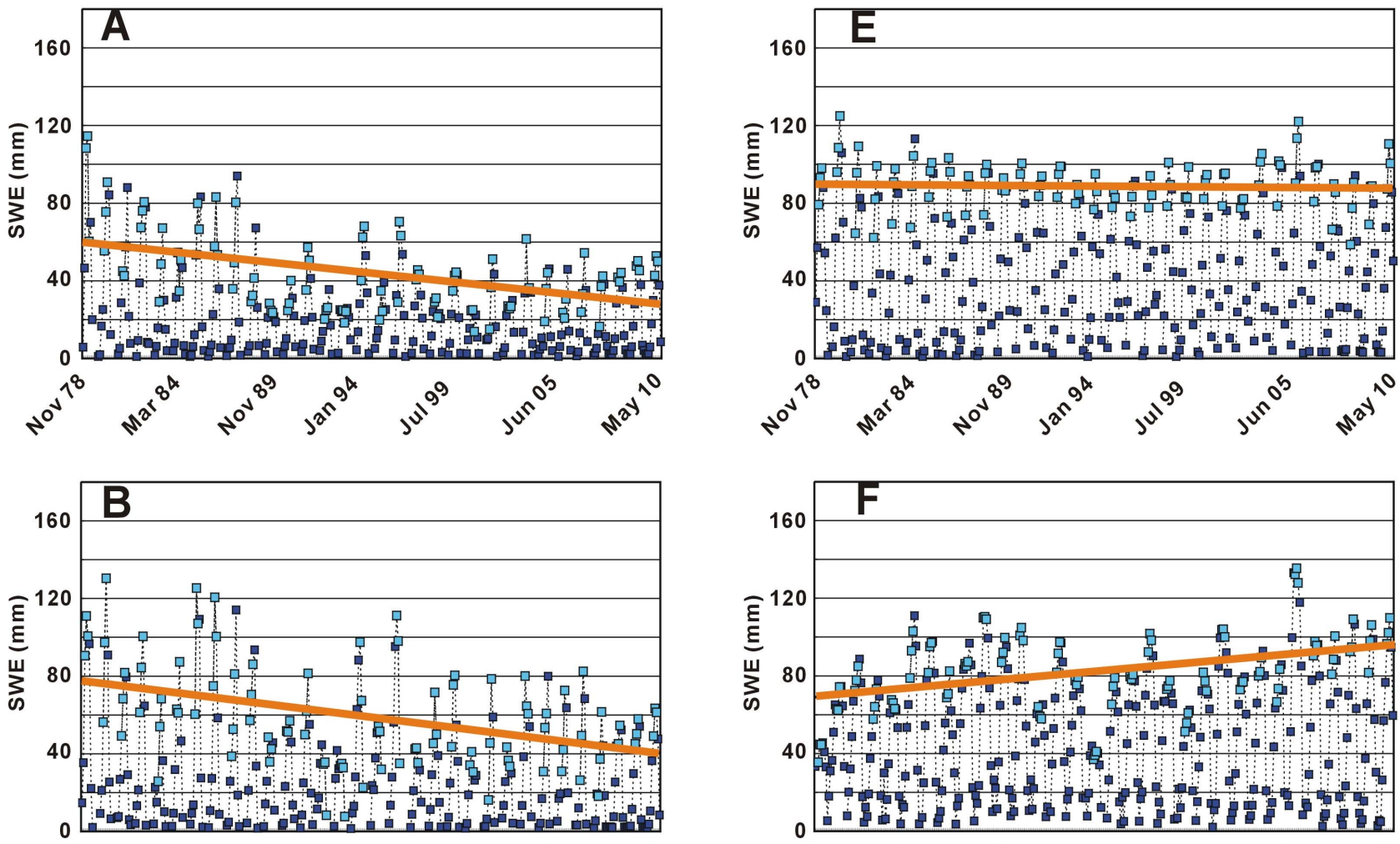

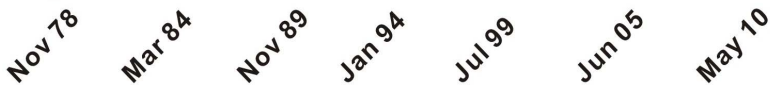

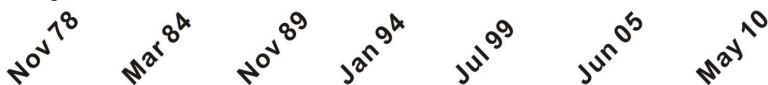
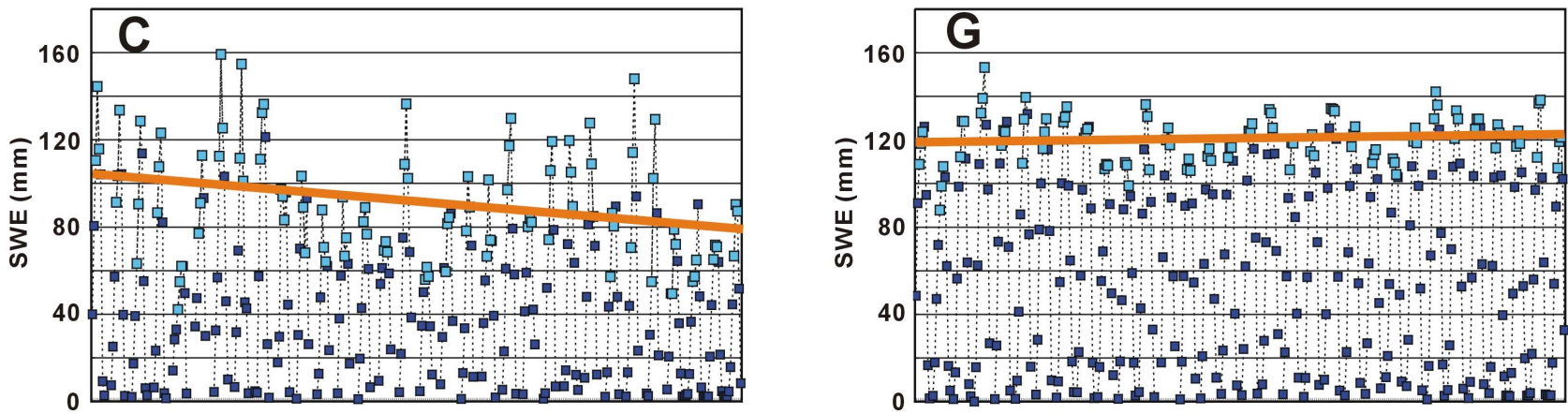

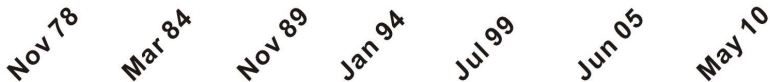

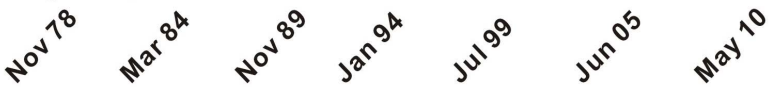
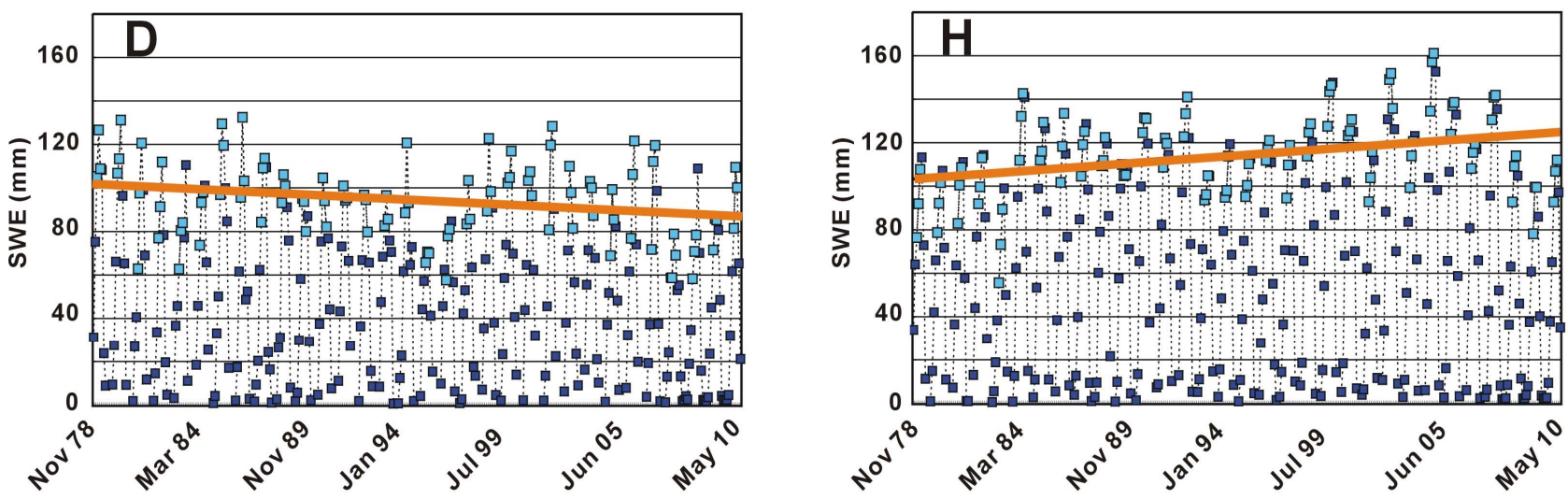

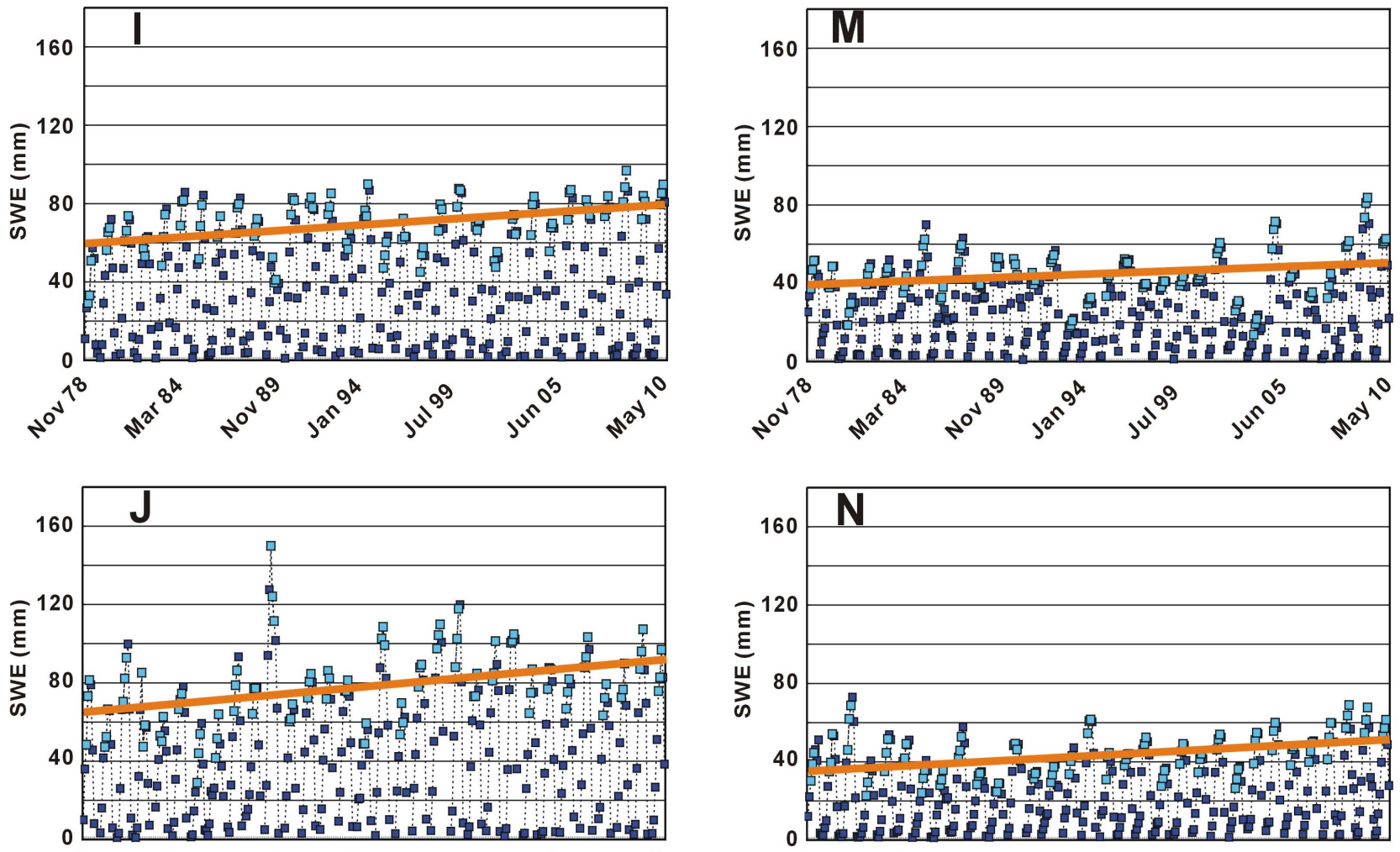

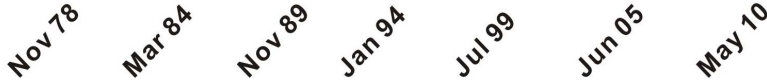
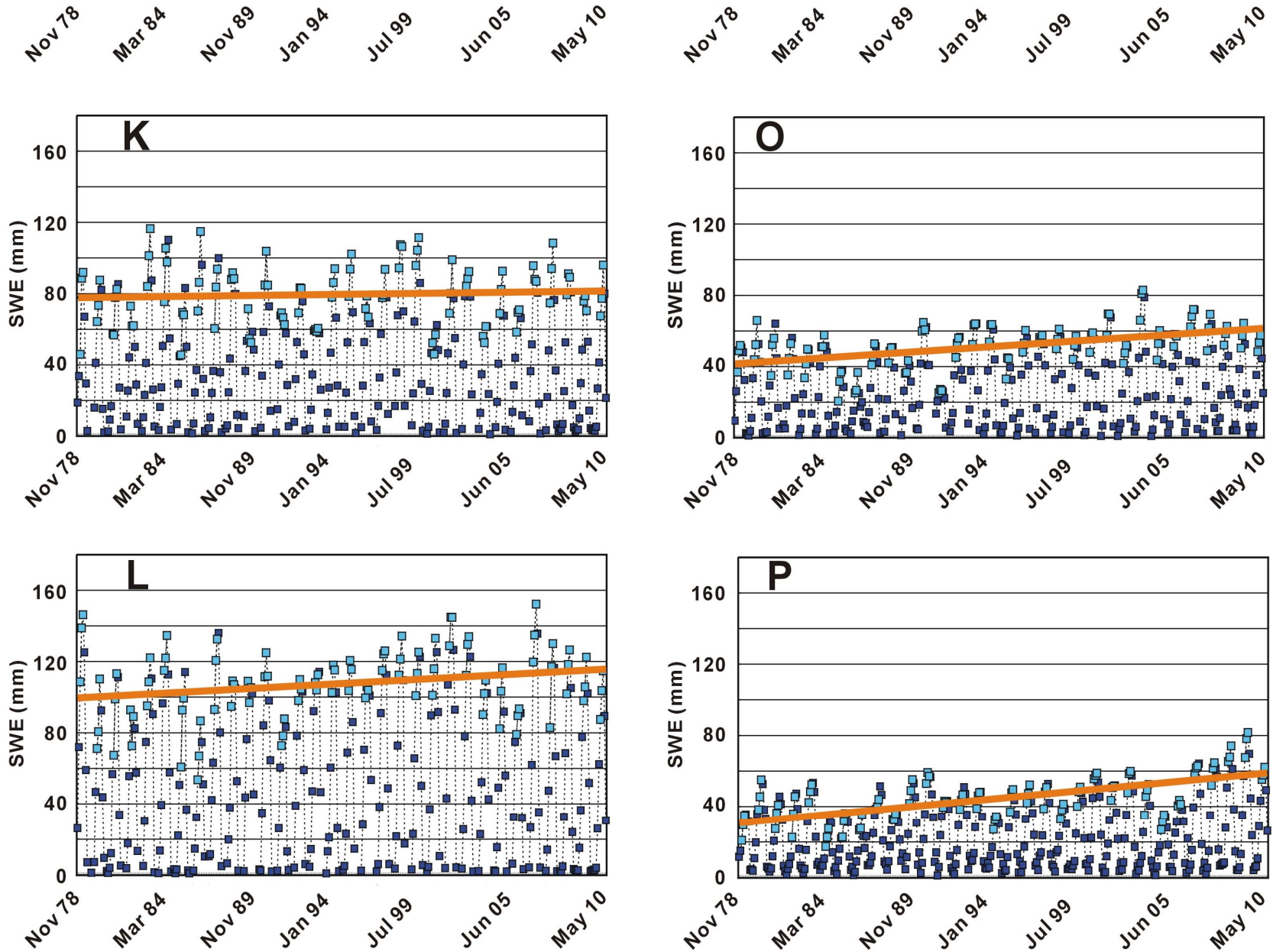

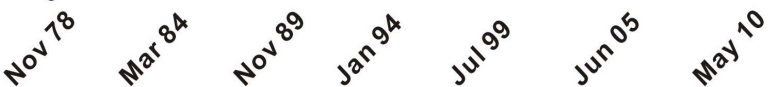



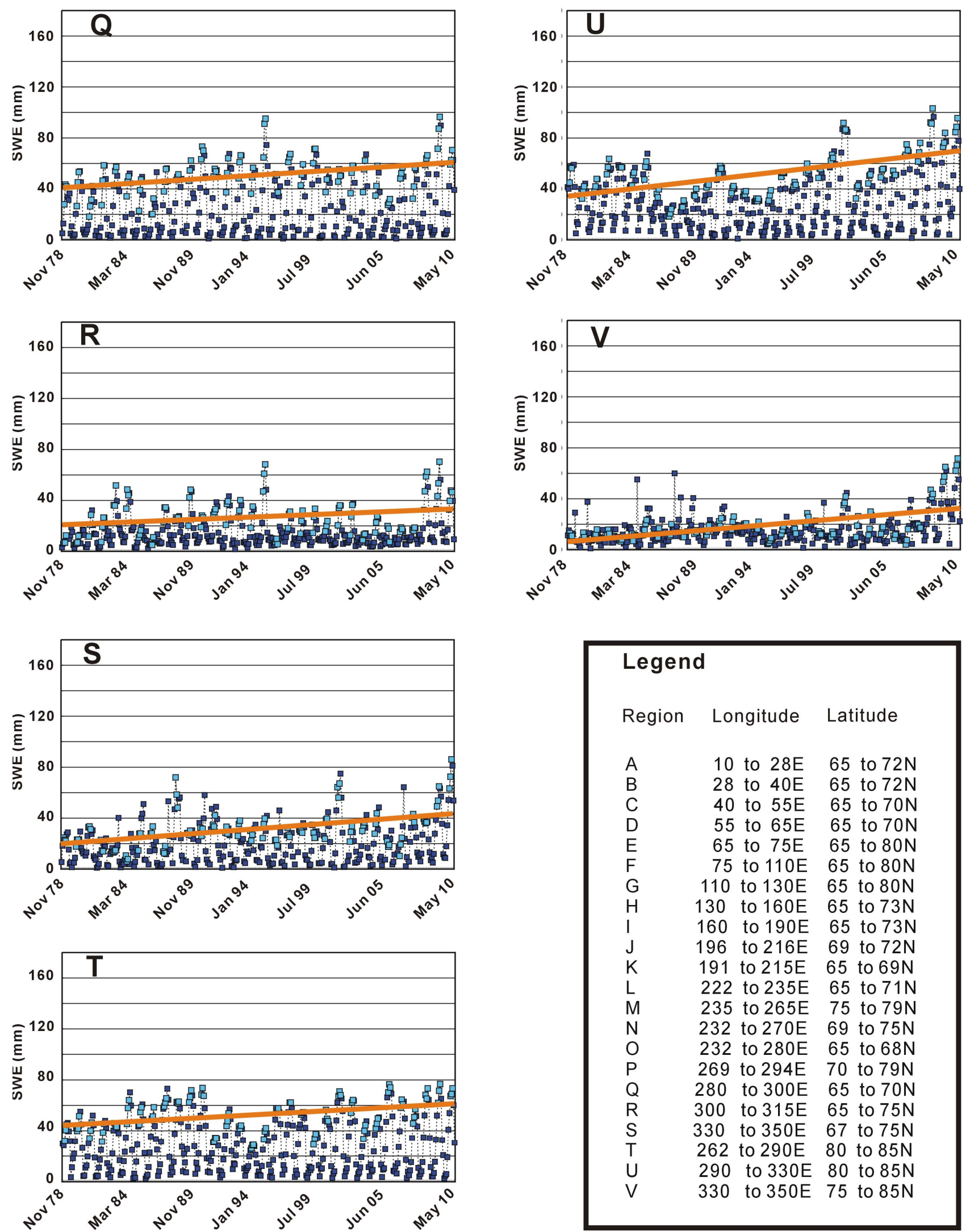

\section{Legend}

Region Longitude Latitude

$\begin{array}{lrr}\text { A } & 10 \text { to } 28 \mathrm{E} & 65 \text { to } 72 \mathrm{~N} \\ \mathrm{~B} & 28 \text { to } 40 \mathrm{E} & 65 \text { to } 72 \mathrm{~N} \\ \mathrm{C} & 40 \text { to } 55 \mathrm{E} & 65 \text { to } 70 \mathrm{~N} \\ \mathrm{D} & 55 \text { to } 65 \mathrm{E} & 65 \text { to } 70 \mathrm{~N} \\ \mathrm{E} & 65 \text { to } 75 \mathrm{E} & 65 \text { to } 80 \mathrm{~N} \\ \mathrm{~F} & 75 \text { to } 110 \mathrm{E} & 65 \text { to } 80 \mathrm{~N} \\ \mathrm{G} & 110 \text { to } 130 \mathrm{E} & 65 \text { to } 80 \mathrm{~N} \\ \mathrm{H} & 130 \text { to } 160 \mathrm{E} & 65 \text { to } 73 \mathrm{~N} \\ \mathrm{I} & 160 \text { to } 190 \mathrm{E} & 65 \text { to } 73 \mathrm{~N} \\ \mathrm{~J} & 196 \text { to } 216 \mathrm{E} & 69 \text { to } 72 \mathrm{~N} \\ \mathrm{~K} & 191 \text { to } 215 \mathrm{E} & 65 \text { to } 69 \mathrm{~N} \\ \mathrm{~L} & 222 \text { to } 235 \mathrm{E} & 65 \text { to } 71 \mathrm{~N} \\ \mathrm{M} & 235 \text { to } 265 \mathrm{E} & 75 \text { to } 79 \mathrm{~N} \\ \mathrm{~N} & 232 \text { to } 270 \mathrm{E} & 69 \text { to } 75 \mathrm{~N} \\ \mathrm{O} & 232 \text { to } 280 \mathrm{E} & 65 \text { to } 68 \mathrm{~N} \\ \mathrm{P} & 269 \text { to } 294 \mathrm{E} & 70 \text { to } 79 \mathrm{~N} \\ \mathrm{Q} & 280 \text { to } 300 \mathrm{E} & 65 \text { to } 70 \mathrm{~N} \\ \mathrm{R} & 300 \text { to } 315 \mathrm{E} & 65 \text { to } 75 \mathrm{~N} \\ \mathrm{~S} & 330 \text { to } 350 \mathrm{E} & 67 \text { to } 75 \mathrm{~N} \\ \mathrm{~T} & 262 \text { to } 290 \mathrm{E} & 80 \text { to } 85 \mathrm{~N} \\ \mathrm{U} & 290 \text { to } 330 \mathrm{E} & 80 \text { to } 85 \mathrm{~N} \\ \mathrm{~V} & 330 \text { to } 350 \mathrm{E} & 75 \text { to } 85 \mathrm{~N}\end{array}$

Figure 6. Regionalized sub-region mean snow water equivalent series and least squares trends. Refer to Table 2 for sub-region trend, p-value and significance level. Longitude in the legend refers to planetocentric, positive East, coordinate graticule. 
Table 2. Regional trends, uncertainties, $\mathbf{P}$-values and significance levels.

\begin{tabular}{|c|c|c|c|c|c|c|}
\hline Region & Longitude & Latitude & Trend & Uncertainty (+/-) & P-Value & $\begin{array}{l}\text { Significance } \\
\text { Level \% }\end{array}$ \\
\hline & & & $\mathrm{mm} / \mathrm{yr}$ & $\mathrm{mm} / \mathrm{yr}$ & & \\
\hline A & 10 to $28 \mathrm{E}$ & 65 to $72 \mathrm{~N}$ & -1.01 & 0.16 & $4.38 \mathrm{E}-13$ & 100.0 \\
\hline B & 28 to $40 \mathrm{E}$ & 65 to $72 \mathrm{~N}$ & -1.17 & 0.21 & 3.73E-12 & 100.0 \\
\hline $\mathrm{C}$ & 40 to $55 \mathrm{E}$ & 65 to $70 \mathrm{~N}$ & -0.79 & 0.23 & $4.71 \mathrm{E}-10$ & 100.0 \\
\hline $\mathrm{D}$ & 55 to $65 \mathrm{E}$ & 65 to $70 \mathrm{~N}$ & -0.46 & 0.16 & $1.55 \mathrm{E}-03$ & 100.0 \\
\hline E & 65 to $75 \mathrm{E}$ & 65 to $80 \mathrm{~N}$ & -0.06 & 0.11 & $8.00 \mathrm{E}-02$ & 91.8 \\
\hline F & 75 to $110 \mathrm{E}$ & 65 to $80 N$ & 0.85 & 0.16 & $1.63 \mathrm{E}-06$ & 100.0 \\
\hline G & 110 to $130 \mathrm{E}$ & 65 to $80 \mathrm{~N}$ & 0.13 & 0.10 & 7.61E-09 & 100.0 \\
\hline $\mathrm{H}$ & 130 to $160 \mathrm{E}$ & 65 to $73 N$ & 0.68 & 0.16 & $1.26 \mathrm{E}-03$ & 99.9 \\
\hline I & 160 to $190 \mathrm{E}$ & 65 to $73 N$ & 0.63 & 0.11 & 3.37E-06 & 100.0 \\
\hline $\mathrm{J}$ & 196 to $216 \mathrm{E}$ & 69 to $72 \mathrm{~N}$ & 0.85 & 0.17 & 3.59E-12 & 100.0 \\
\hline $\mathrm{K}$ & 191 to $215 \mathrm{E}$ & 65 to $69 \mathrm{~N}$ & 0.01 & 0.01 & 4.77E-05 & 100.0 \\
\hline $\mathrm{L}$ & 222 to $235 \mathrm{E}$ & 65 to $71 \mathrm{~N}$ & 0.51 & 0.17 & $2.00 \mathrm{E}-02$ & 98.2 \\
\hline M & 235 to $265 \mathrm{E}$ & 75 to $79 N$ & 0.35 & 0.12 & $1.00 \mathrm{E}-02$ & 99.1 \\
\hline $\mathrm{N}$ & 232 to $270 \mathrm{E}$ & 69 to $75 N$ & 0.51 & 0.09 & $1.79 \mathrm{E}-10$ & 100.0 \\
\hline $\mathrm{O}$ & 232 to $280 \mathrm{E}$ & 65 to $68 \mathrm{~N}$ & 0.62 & 0.10 & $2.76 \mathrm{E}-08$ & 100.0 \\
\hline $\mathrm{P}$ & 269 to $294 \mathrm{E}$ & 70 to $79 \mathrm{~N}$ & 0.87 & 0.09 & $3.50 \mathrm{E}-12$ & 100.0 \\
\hline $\mathrm{Q}$ & 280 to $300 \mathrm{E}$ & 65 to $70 \mathrm{~N}$ & 0.64 & 0.12 & $1.24 \mathrm{E}-13$ & 100.0 \\
\hline $\mathrm{R}$ & 300 to $315 \mathrm{E}$ & 65 to $75 N$ & 0.41 & 0.13 & $1.52 \mathrm{E}-10$ & 100.0 \\
\hline $\mathrm{S}$ & 330 to $350 \mathrm{E}$ & 67 to $75 \mathrm{~N}$ & 0.75 & 0.12 & $5.48 \mathrm{E}-10$ & 100.0 \\
\hline $\mathrm{T}$ & 262 to $290 \mathrm{E}$ & 80 to $85 N$ & 0.55 & 0.11 & $1.78 \mathrm{E}-05$ & 100.0 \\
\hline $\mathrm{U}$ & 290 to $330 \mathrm{E}$ & 80 to $85 N$ & 1.12 & 0.13 & $1.63 \mathrm{E}-06$ & 100.0 \\
\hline V & 330 to $350 \mathrm{E}$ & 75 to $85 N$ & 0.83 & 0.11 & $2.18 \mathrm{E}-10$ & 100.0 \\
\hline
\end{tabular}

co-locate the snow water equivalents to the high-resolution ESA funded Altimetry Corrected Digital Elevation version 2 Digital Elevation Model. Then we derive hemispheric wide and regionalized snow water equivalent trends and significance levels on non-glaciated lands in the elevation range of 0 up to $100 \mathrm{~m}$. These correspond to low-elevation tundra landscapes. Our results indicate significantly increasing trends of snow water equivalent from northern Siberia through North America and northern Greenland of varying magnitude. Across northern Norway through northwest Russia there are significantly decreasing trends of snow water equivalent. Power density spectra identify significant power at quasi-biennial and associated lunar nodal cycles. These cycles of the upper atmosphere circulation, ENSO and ocean circulation perturbations from tides forms the causative linkage between increasing snow water equivalent on low-elevation tundra landscapes and decreasing coastal sea ice cover as a subsystem of the Arctic system energy and mass cycles.

\section{Acknowledgements}

We thank the Arctic Region Supercomputing Center, University of Alaska Fairbanks for their computational facilities support. Dr. Vladimir E. Romanovsky, Geophsical Institute University of Alaska Fairbanks encouraged the research. The Generic Mapping Tools (http://gmt.soest. hawii.edu) and MATLAB were used in this research.

\section{REFERENCES}

[1] M. C. Serreze, D. H. Bromwich, M. P. Clark, A. J. Etringer, T. Zhang and R. Lammers, "Large-Scale Hydor-Climatology of the Terrestrial Arctic Drainage System,” Journal of Geophysical Research, Vol. 108, No. D2, 2003, pp. 8160-8187. doi:10.1029/2001JD000919

[2] A. G. Bunn, S. J. Goetz, J. S. Kimball and K. Zhang, "Northern High-Latitude Ecosystems Respond to Climate Change," Eos Transactions American Geophysical Union, Vol. 88, No. 34, 2007, pp. 333-334.

[3] D. White, L. Hinzman, L. Alessa, J. Cassano, M. Cham- 
bers, K. Falkner, J. Francis, W. J. Gutowski Jr., M. Holland, R. M. Holmes, H. Huntington, D. Kane, A. Kliskey, C. Lee, J. McClelland, B. Peterson, T. S. Rupp, F. Straneo, M. Steele, R. Woodgate, D. Yang, K. Yoshikawa and T. Zhang, "The Arctic Freshwater System: Changes and Impacts,” Journal of Geophysical Research, Vol. 112 2007, G04S54. doi:10.1029/2006JG000353

[4] U. S. Bhatt, D. A. Walker, M. K. Raynolds, J. C. Comiso, H. E. Epstein, G. Jia, R. Gens, J. E. Pinzon, C. J. Tucker, C. E. Tweedie and P. J. Webber, "Circumpolar Arctic Tundra Vegetation Change Is Linked to Sea Ice Decline,” Earth Interactions, Vol. 14, No. 8, 2010, pp. 1-20, doi:10.1175/2010EI315.1

[5] G. Grosse, S. Marchenko, V. Romanovsky, K. P. Wickland, N. French, M. Waldrop, L. Bourgeau-Chavez, R. Striegl, J. Harden, M. Turetsky, A. D. McGuire, P. Camill, C. Tarnocai, S. Frolking, E. Schuur and T. Jorgenson, "Vulnerability of High Latitude Soil Organic Carbon in North America to Disturbance," Journal of Geophysical Research, Vol. 116, 2011, G00K06. doi:10.1029/2010JG001507

[6] R. E. Dickinson, "Land Surface Processes and Climate -Surface Albedos and Energy Balance,” In: B. Saltzman, Ed., Advances in Geophysics, Theory of Climate, Vol. 25, Academic Press, New York, 1983.

[7] B. F. Chao, W. P. O’Connor, A. T. C. Chang, D. K. Hall and J. L. Foster, "Snow Load Effect on the Earth's Rotation and Gravitational Field, 1979-1985," Journal of Geophysical Research, Vol. 92, No. B9, 1987, pp. 9415-9422. doi:10.1029/JB092iB09p09415

[8] C. K. Seyfert and L. A. Sirkin, "Earth History and Plate Tectonics: An Introduction to Historical Geology,” 2nd Edition, Harper \& Row Publishers, Inc., New York, 1979.

[9] P. J. Brockwell and R. A. Davis, "Time Series: Theory and Methods," 2nd Edition, Springer-Verlag, New York, 1991. doi:10.1007/978-1-4419-0320-4

[10] P. R. Bevington and D. K. Robinson, "Data Reduction and Error Analysis for the Physical Sciences,” 2nd Edition, McGraw-Hill Inc., New York, 1992.

[11] J. A. Scales, M. L. Smith and S. Treitel, "Introductory Inverse Theory,” Samizdat Press, Golden, 2001.

[12] G. J. Borradaile, "Statistics of Earth Science Data: Their Distribution in Space, Time and Orientation," SpringerVerlag, Berlin, 2003.

[13] K. F. Kunzi, S. Patil and H. Rott, "Snow-Cover Parameters Retrieved from Nimbus-7 Scanning Multichannel Microwave Radiometer (SMMR) Data," IEEE Transactions on Geoscience and Remote Sensing, Vol. 20, No. 4, 1982, pp. 452-467. doi:10.1109/TGRS.1982.350411

[14] A. T. C. Chang, J. L. Foster and D. K. Hall, "Nimbus-7 SMMR Derived Global Snow Cover Parameters,” Annals of Glaciology, Vol. 9, 1987, pp. 39-44.

[15] A. T. C. Chang, J. L. Foster and D. K. Hall, "Satellite Sensor Estimates of Northern Hemisphere Snow Volume,” International Journal of Remote Sensing, Vol. 11, No. 1, 1990, pp. 167-171. doi:10.1080/01431169008955009

[16] L. S. Koenig and R. R. Forster, "Evaluation of Passive
Microwave Snow Water Equivalent Algorithms in the Depth Hoar-Dominated Snowpack of the Kuparuk River Watershed, Alaska, USA,” Remote Sensing of Environment, Vol. 93, No. 4, 2004, pp. 511-527. doi:10.1016/j.rse.2004.08.004

[17] E. G. Njoku, “Antenna Pattern Correction Procedures for the Scanning Multichannel Microwave Radiometer (SMMR)," Boundary-Layer Meteorology, Vol. 18, 1980, pp. 79-98. doi:10.1007/BF00117912

[18] A. T. C. Chang, J. L. Foster and D. K. Hall, "Effects of Forest on the Snow Parameters Derived from Microwave Measurements during the BOREAS Winter Field Campaign,” Hydrological Processes, Vol. 10, No. 12, 1996, pp. 1565-1574. doi:10.1002/(SICI)1099-1085(199612)10:12<1565::AIDHYP501>3.0.CO;2-5

[19] R. J. Armstrong and M. J. Brodzik, "Recent Northern Hemisphere Snow Extent: A Comparison of Data from Visible and Microwave Satellite Sensors,” Geophysical Research Letters, Vol. 28, No. 19, 2001, pp. 3673-3676. doi:10.1029/2000GL012556

[20] A. T. C. Chang, J. L. Foster, D. K. Hall, B. E. Goodison, A. E. Walker and J. R. Metcalfe. "Snow Parameters Derived from Microwave Measurements during the BOREAS Winter Field Experiment,” Journal of Geophysical Research, Vol. 102, No. D24, 1997, pp. 29663-29671. doi:10.1029/96JD03327

[21] R. Kelly, A. Chang, L. Tsang and J. Foster, “A Prototype AMSR-E Global Snow Area and Snow Depth Algorithm," IEEE Transactions on Geoscience and Remote Sensing, Vol. 41, No. 2, 2003, pp. 230-242. doi:10.1109/TGRS.2003.809118

[22] R. E. J. Kelly and A. T. C. Chang, "Development of a Passive Microwave Global Snow Depth Retrieval Algorithm for Special Sensor Microwave Imagery (SSM/I) and Advanced Microwave Scanning Radiometer-EOS (AMSR-E) Data,” Radio Science, Vol. 38, No. 4, 2003, pp. 1-11. doi:10.1029/2002RS002648

[23] R. J. Kelly and J. L. Foster, “The AMSR-E Snow Water Equivalent Product: Status and Future Development," American Geophysical Union, Fall Meeting 2005, Abstract \#C21C-1134, 2005.

[24] R. E. J. Kelly, J. L. Foster and D. K. Hall, “The AMSR-E Snow Water Equivalent Product: Algorithm Development and Progress in Product Validation," Proceedings of the 28th General Assembly of the Union of International Radio Science, New Delhi, 23-29 October 2005.

[25] S. Biancamaria, N. Mognard, A. Boone, M. Grippa and E. Josberger, "A Satellite Snow Depth Multi-Year Average Derived from SSM/I for the High Latitude Regions," Remote Sensing of Environment, Vol. 112, No. 5, 2008, pp. 2557-2568. doi:10.1016/j.rse.2007.12.002

[26] C. Derksen, P. Toose, A. Rees, L. Wang, M. English, A. Walker and M. Sturm, "Development of a Tundra-Specific Snow Water Equivalent Retrieval Algorithm for Satellite Passive Microwave Data," Remote Sensing of Environment, Vol. 114, No. 8, 2010, pp. 1699-1709. doi:10.1016/j.rse.2010.02.019

[27] D. K. Hall, R. E. J. Kelly, G. A. Riggs, A. T. C. Chang 
and J. L. Foster, "Assessment of the Relative Accuracy of Hemispheric-Scale Snow-Cover Maps,” Annals of Glaciology, Vol. 34, 2002, pp. 24-30.

[28] J. L. Foster, C. Sun, J. P. Walker, R. Kelly, A. Chang, J. Dong and H. Powell, "Quantifying the Uncertainty in Passive Microwave Snow Water Equivalent Observations,” Remote Sensing of Environment, Vol. 94, No. 2, 2005, pp. 187-203. doi:10.1016/j.rse.200409.012

[29] J. T. Pulliainen, J. Grandell and M. T. Hallikainen, "Retrieval of Surface Temperature in Boreal Forest Zone from SSM/I Data,” IEEE Transactions on Geoscience and Remote Sensing, Vol. 35, No. 5, 1997, pp. 1188-1200. doi:10.1109/36.628786

[30] A. T. C. Chang, J. L. Foster, R. E. J. Kelly, E. G. Josberger, R. L. Armstrong and N. M. Mognard, "Analysis of Ground-Measured and Passive-Microwave-Derived Snow Depth Variations in Midwinter across the Northern Great Plains," Journal of Hydormet, Vol. 6, No. 1, 2005, pp. 20-33. doi:10.1175/JHM-404.1

[31] R. J. Armstrong, M. J. Brodzik, K. Knowles and M. Savoie, "Global Monthly EASE-Grid Snow Water Equivalent Climatology,” National Snow and Ice Data Center, University of Colorado Boulder, 2007.

http://nsidc.org/data/docs/daac/nsidc0271_ease_grid_swe _climatology.gd.html

[32] A. T. C. Chang and A. Rango, “Algorithm Theoretical Basis Document for the AMSR-E Snow Water Equivalent Algorithm, Version 3.1,” NASA Goddard Space Flight Center, 2000.

http://nsidc.org/data/amsre/pdfs/amsr_atbd_snow.pdf

[33] M. Tedesco, R. E. J. Kelly, J. L. Foster and A. T. C. Chang, "AMSR-E/Aqua Monthly L3 Global Snow Water Equivalent EASE-Grids V002,” National Snow and Ice Data Center, University of Colorado Boulder, 2004. http://nsidc.org/data/docs/daac/ae_swe_ease-grids.gd.htm 1.

[34] F. G. Lemoine, S. C. Kenyon, J. K. Factor, R. G. Trimmer, N. K. Palvis, D. S. Chinn, C. M. Cox, S. M. Klosko, S. B. Luthcke, M. H. Torrence, Y. M. Wang, R. G. Williamson, E. C. Pavlis, R. H. Rapp and T. R. Olson, "The Development of the Joint NASA GSFC and the National Imagery and Mapping Agency (NIMA) Geopotential Model EGM96," NASA Goddard Space Flight Center, NASA/ TP-1998-206861, Maryland, 1998.

[35] National Imagery and Mapping Agency (NIMA), "Department of Defense World Geodetic System 1984: Its Definition, and Relationship with Local Geodetic Systems, TR8350.2, Third Ed., Ammendment 1,” Department of Defense, Washington DC, 2000.

[36] Z. Altamimi, X. Collilieux, J. Legrand, B. Garayt and C. Boucher, "ITRF2005: A New Release of the International Terrestrial Reference Frame on Time Series of Station Positions and Earth Orientation Parameters," Journal of Geophysical Research, Vol. 112, 2007, B09401. doi:10.1029/2007JB004949

[37] P. A. M. Berry, R. G. Smith, J. A. Freeman and J. Benveniste, "Towards a New Global Digital Elevation Model,” In: M. G. Sideris, Ed., Observing Our Change Earth, Vol. 133, Part 2, 2008, pp. 431-435. http://tethys.eaprs.cse.dum.ac.uk

[38] R. G. Smith, P. A. M. Berry and J. Benveniste, "Representation of Rivers and Lakes within the Forthcoming ACE2 Global Digital Elevation Model," ESA 2nd Space for Hydrology Workshop, Geneva, 12-14 November 2007. http://earth.esa.int/hydrospace07/participants/04_03/04_0 3_Smith.pdf

[39] K. E. Trenberth, "Recent Observed Interdacadal Climate Changes in the Northern Hemisphere," Bulletin of the American Meteorological Society, Vol. 7, 1990, pp. 988993. doi:10.1175/1520-0477(1990)071<0988:ROICCI >2.0.CO ;2

[40] G. Wang and P. Yang, "A Compound Reconstructed Prediction Model for Nonstationary Climate Processes," International Journal of Climatology, Vol. 25, No. 9, 2005, pp. 1265-1277. doi:10.1002/joc.1158

[41] A. Dai and T. M. L. Wigley, "Global Patterns of ENSOInduced Precipitation,” Geophysical Research Letters, Vol. 27, No. 9, 2000, pp. 1283-1286. doi:10.1029/1999GL011140

[42] O. Timm, M. Pfeiffer and W.-C. Dullo, "Nonstationary ENSO-Precipitation Teleconnections over the Equatorial Indian Ocean Documented in a Coral from the Chagos Archipelago," Geophysical Research Letters, Vol. 32, 2005, L02701. doi:10.1029/2004GL021738

[43] D. W. J. Thompson and J. M. Wallace, "Annular Modes in the Extratropical Circulation. Part I: Month-to-Month Variability,” Journal of Climate, Vol. 13, No. 5, 2000, pp. 1000-1016.

doi:10.1175/1520-0442(2000)013<1000:AMITEC>2.0.C $\underline{\mathrm{O} ; 2}$

[44] S. B. Feldstein, "The Timescale, Power Spectra, and Climate Noise Properties of Teleconnection Patterns," Journal of Climate, Vol. 13, No. 24, 2000, pp. 4430-4440.

[45] R. J. Allen and C. S. Zender, "The Role of Eastern Siberican Snow and Soild Moisture Anomalies in QuasiBiennial Persistence of the Arctic and North Atlantic Oscillations," Journal of Geophysical Research, Vol. 116, 2011, D16125. doi:10.1029/2010JD015311

[46] H. Yndestad, "The Influence of the Lunar Nodal Cycle on Arctic Climate,” ICES Journal of Marine Science, Vol. 63, No. 3, 2006, pp. 401-420.

[47] I. D. Haigh, M. Eliot and C. Pattiaratci, "Global Influences of the 18.61 Year Nodal Cycle and the 8.85 Year Cycle of Lunar Perigee on High Time Levels,” Journal of Geophysical Research, Vol. 116, 2011, C06025. doi:10.1029/2010JC006645

[48] M. Shulski and G. Wendler, "The Climate of Alaska," University of Alaska Press, Fairbanks, 2007.

[49] D. Ghatak, A. Frei, G. Gong, J. Stroeve and D. Robinson, "On the Emergence of an Arctic Amplification Signal in Terrestrial Arctic Snow Extent,” Journal of Geophysical Research, Vol. 115, 2010, D24105. doi:10.1029/2010JD014007

[50] G. Wendler, M. Shulski and B. Moore, "Changes in the Climate of the Alaskan North Slope and the Ice Concentration of the Adjacent Beaufort Sea," Theoretical and 
Applied Climatology, Vol. 99, No. 1, 2010, pp. 67-74. doi:10.1007/s00704-009-0127-8

[51] M. C. Serreze, A. P. Barrett, A. G. Slater, R. A. Woodgate, K. Aagaard, R. B. Lammers, M. Steele, R. Moritz,
M. Merrdith and C. M. Lee, "The Large-Scale Freshwater Cycle of the Arctic," Journal of Geophysical Research, Vol. 111, 2006, C11010. doi:10.1029/2005JC003424 